\title{
Right to Fair Trial from the Perspectives of Slovak Legal Acts and the European Law viz. Directive (EU) 2016/343
}

\author{
DANIEla Novackova, Darina SAXUNOVA \& JARMILA WEFERSOVA
}

\begin{abstract}
The objective of the study was to analyse the transposition of the Directive (EU) 2016/343 of the European Parliament and of the Council on the strengthening of certain aspects of the presumption of innocence and of the right to be present at the trial in criminal proceedings. In the Slovak legal order, this Directive's transposition highlights the responsible attitude of the Slovak Republic to fulfil the obligations arising from EU membership. The system of protection of suspected persons from committing crimes is regulated in several Slovak legislation. After analysis and comparison with the European legal framework discrepancies in Slovak And European legislation have been highlighted and an amendment has been incorporated into amended legislation.
\end{abstract}

Keywords: • right to fair trial • Directive (EU) 2016/343 • criminal proceeding $\bullet$ legislation $\bullet$ Slovakia

Correspondence AdDress: Daniela Novackova, Ph.D., Professor, Comenius University in Bratislava, Faculty of Management, Odbojárov 10, 83104 Nové Mesto, Slovakia, email: daniela.novackova@fm.uniba.sk. Darina Saxunova, Ph.D., Associate Professor, Comenius University in Bratislava, Faculty of Management, Odbojárov 10, 83104 Nové Mesto, Slovakia, email: darina.saxunova@fm.uniba.sk. Jarmila Wefersova, Comenius University in Bratislava, Faculty of Management, Odbojárov 10, 83104 Nové Mesto, Slovakia, email: jarmila.wefersonova@fm.uniba.sk.

https://doi.org/10.4335/978-961-6842-96-9.59-66

ISBN 978-961-6842-96-9 (pdf)

(C) 2020 Institute for Local Self-Government Maribor

Available online at http://www.lex-localis.press. 
When a person is accused of a crime, or involved in some other legal dispute, having the right to a fair trial should be necessity in a democratic society. What does it mean? A charged person with a crime has the right to a fair and public hearing, that commences within a reasonable time, and is executed by an independent and impartial court. If this does not happen the accused may submit a complaint to the European Court of Human Rights. It has been coping with a great deal of cases of unfair trials - even examples which resulted in imprisoning an innocent person. The European Convention on Human Rights assists people to get a retrial and to assure and monitor that governments strive to constitute appropriate legislation to avoid miscarriages of justice. Famous cases have been, for instance, a) due to excessive delays to legal proceedings; b) due to arbitrary detention in a psychiatric hospital against the person's will, violating his right to liberty; c) because of unjust verdict leading to imprisoning the innocent person; d) because of being the victim of political corruption; e) due to a failure to investigate attack on Roma settlement and many others.

The aim of the study was to analyse the transposition of the Directive (EU) 2016/343 of the European Parliament and of the Council of 9 March 2016 on the strengthening of certain aspects of the presumption of innocence and of the right to be present at the trial in criminal proceedings (Ú. v. EÚ L 65, 11.3.2016, pp.. 1-11) which is in Slovak language as "Smernica o posilnení určitých aspektov prezumpcie neviny a práva byt' prítomný na konaní pred súdom v trestnom konaní". In the Slovak legal order, this Directive's transposition highlights the responsible attitude of the Slovak Republic to fulfil the obligations arising from EU membership. The system of protection of suspected persons from committing crimes is regulated in several Slovak legislation. In terms of comparing the transposition of the EU Directive with the Slovak legal order, a full degree of approximation of law has been achieved. In managing the study, we used the relevant EU legislation and the Slovak legislation in force. The European Commission has not yet taken any measure in respect of the Slovak Republic in terms of unsatisfactory transposition. The right to a fair trial was enacted first time in the context of the Constitution of the Slovak Republic.

\section{Right to fair trial in the context of Slovak legal acts and in the European law}

The current Slovak legal order is to a large extend influenced by the legal acts of the European Union, as well as by the international agreements and treaties binding on the Slovak Republic.

Rights granted to an individual that form part of the right to fair trial are enshrined especially in the Fifth Chapter of the Slovak Charter of Fundamental Rights and Basic Freedoms adopted in 1991 as well as in the Constitution of the Slovak Republic (Act No 
460/1992 as amended). The Slovak Constitution represents the basic act and takes precedence over any other legislative acts. According to the Constitution a punishment may be imposed on a person only in accordance with the law and in the manner laid down by the relevant laws. These laws are the Criminal Code as well as the Criminal Procedure Code, which establish the rules for criminal proceedings, including specific conditions for exercising and enforcing rights of individuals. According to Article 1 paragraph 2 of the Constitution the Slovak Republic acknowledges and adheres to general rules of international law, international treaties by which it is bound, and its other international obligations. In this provision the relationship of the Slovak Republic to the international conventions, treaties and other acts acceded to by the Slovak Republic and are binding on it. Among such international treaties also ranks the Treaty on the Functioning of the European Union, the Charter of Fundamental Rights of the European Union and the European Convention on Human Rights and Fundamental Freedoms. Article 7 paragraph 2 of the Slovak Constitution states explicitly the obligation to transpose the directives into the internal legal order. In this connection, we can also talk about the constitutional principle, according to which the Slovak Republic recognizes and honours general rules of international law, international treaties by which it is bound and its other international obligations.

The right to fair trial is also guaranteed by Article 48 paragraph 2 of the Constitution which stipulates that everyone has the right to have his case tried in public, without undue delay, and in his presence and to deliver his opinion on all pieces of evidence.

Another provision stipulating the procedural rights in the context of fair trial are enshrined in Article 50 of the Constitution, according to which the guilt and punishment shall be established only by the decision of the court (no punishment without the law). Another principles specifically guaranteed in this provision are the presumption of innocence, right to legal counsel, right to self defence, right to refuse to testify, as well as the principle ne bis in idem and the right to more favourable sanction.

Article 141 of the Constitution enshrines the principle of independence of courts that undoubtedly represents the traditional constitutional principle. It is the independence together with the impartiality of the courts that forms part of the right to fair trial.

Article 81 of the Constitution guarantees the independence of courts and the administration by independent and impartial courts. Undoubtedly this represents the traditional constitutional principle that forms part of the right of fair trial and the right for impartial and independent courts. The judiciary as a whole represents the guarantee and thus being the part of the independence of every individual judge who applies and interprets directly the law. Another aspect that forms part of right to fair trial is the fact that the judge is bound by the law and applicable international treaty, as it is stipulated by 
article 144 of the Constitution. This provision represents the constitutional expression of independence of judges.

In this context it is important to note, that also the Court of Justice of the EU has distinguished this aspect of judicial independence, especially in case C-506/04 Graham J. Wilson v. Ordre des avocats du barreau de Luxembourg. The Court of Justice makes the difference between the external aspect of judicial independence presuming the protection of the court against external influence or pressure, which could endanger the independent assessment of concrete case by the court and its judges. The internal aspect of independence entails the capacity to render judgement that is independent and based only by the law.

\section{Right to fair trial in the context of international conventions and the European law}

The doctrine of fair trial is also enforced by virtue of transnational systems as stipulated by the international treaties involving the judicial systems. In particular this is the case of the jurisprudence of the European Court on Human Rights deciding on the basis of European Convention on the Protection of Human Rights and Fundamental Freedoms, forming so called Strasbourg pillar of the human rights protection. Another transnational mechanism is established by the primary law of the European Union and its enforcement mechanism is created by the system of courts of the EU, forming the so called Luxembourg pillar. As for the secondary law of the EU, together along with the "Lisbonisation" of the formal third pillar the significant strengthening of the protection of procedural rights of suspect and accused persons has taken place, through adopting several measures included in the Road Map for strengthening procedural rights of suspected or accused persons in criminal proceedings adopted by the resolution of the Council of 30 November 2009 (OJ C 295, 4.12.2009, p. 1-3).

\subsection{European Convention}

According to Article 6 of the European Convention on Human Rights everyone is, in determination of his or her civil rights and obligation or of any criminal charges, entitled to fair and public hearing within a reasonable time by an independent and impartial tribunal established by law. Thus the context of the right to fair trial means the right to have the case decided in fair and public matter in the reasonable time by the independent court deciding about civil rights and obligations or about any criminal charges.

The provision of Article 6 of the European Convention on Human rights is relatively extensive in terms of its length, but also in terms of enumerating the specific rights that are designed to form part of the right to fair trial. The right for fair judicial decision is also comprised in this catalogue of Article 6. The notion of "fair decision" is not defined in the European nor in the national level. At the same time in the criminal proceedings 
the fair decision can only be considered the decision that is adequate as to the imposed punishment or function and as to the person of offender. It is also important to note that the principle of fairness is in the context of the Convention as well as in the context of several recommendations of the Committee of Ministers of the Council of Europe is related both to the person of offender as well as to the interest of society. It is important in the application of this principle to comply with the principle of legality and individualization of sanctions.

Right to fair trial is at the EU level also regulated by the Directive (EU) 2016/343 of the European Parliament and of the Council of 9 March 2016 on the strengthening of certain aspects of the presumption of innocence and of the right to be present at the trial in criminal proceedings. This Directive contributes to the general aim of strenghtening the mutual trust by stipulating the catalogue of common minimal rules for the procedural rights in the criminal proceedings. At the same time it contributes to the improvement of the application of the principle of fair trial that represents the milestone of the space of freedom, security and justice in the EU. It helps to uphold the mutual trust through ensuring the more consistent enforcement of the right to fair trial as stipulated by Article 47 of the Charter of Fundamental Rights of the European Union ${ }^{1}$ and Article 6 of the European Convention on Human Rights.

\subsection{European Law}

Five other directives have been adopted at the EU level concerning:

1. right to information about rights and charges and access to the court case file:

2. right of access to a lawyer and communication with third persons while being deprived of liberty ;

3. strengthening of certain aspects of the presumption of innocence and of the right to be present at the trial ;

4. procedural safeguards for children; and

5. legal aid

The Directive on the presumption of innocence has been in the Slovak Republic transposed by the Law on the European Investment Order in Criminal Matters and on the amendment of other laws No. 236/2017 Coll. as well as by the Code of Criminal Procedure No. 301/2005 Coll.

The Directive contains the provisions aiming at the strengthening the right to fair trial in the criminal proceedings through the setting the minimum rules relating certain aspects of the presumption of innocence and the right to be present at the court hearing. The catalogue of rights of person involved in the criminal proceedings regulated by the Code of Criminal Procedure and in the Law on European Investment Order in Criminal Matters are following: 

of Slovak Legal Acts and the European Law viz. Directive (EU) 2016/343

a) Law enforcement authorities are acting swiftly and taking fully into account fundamental rights and freedoms;

b) Law enforcement authorities act in such a way to avoid any reasonable doubts about the facts necessary in order to issue the decision, while fully taking into account the evidence;

c) Right of a detained person to express to all charges and related evidence;

d) Right to refuse to testify;

e) Right to inspect court files, to make notices and extracts, as well as copies;

f) Right to take part in the court hearings, right to have final speech during the court proceedings;

g) Right to present proposals for taking the evidence and way of decision making and to file applications;

h) Right to remedy;

i) Right for legal counsel;

j) Right to talk to the legal counsel without the presence of third person;

k) Right to use the mother tongue or other language according to one's choice in the contact with the law enforcement authorities.

\subsubsection{Fundamental Principles of Criminal Procedure applied at present}

In its Article 1 the Directive regulates the minimum rules applicable to certain aspects of the right of presumption of innocence. The aim of this provision is to ensure the rights of suspect and accused persons so that they would not be in public statements and official decisions of public authorities indicated as guilty without the final sentence of the court. This also includes the principle of in dubio of reo decision as well as the right to refuse the testimony.

These rights regulating the presumption of innocence are already guaranteed in the valid legislation of the Slovak Republic, more specifically in particular in the Code of Criminal Procedure as the fundamental principles of criminal procedure in its Article 2 paragraph 4 and Article 6 paragraph 2. At the same time this Article regulates the right to be present at the hearing before the court, which is included in the Code of Criminal Procedure, in particular in its Article 358 regulating the proceedings held in absentia.

Article 4 of the Directive stipulates the right of suspect persons or accused persons not to be referred as being guilty in the public statements and decisions of public authorities before the final judgement is rendered. This right is guaranteed in the Slovak legal regulation and it is enshrined also in the introductory fundamental principles of Code of Criminal Procedure in its Article 2 and Article 6.

Article 7 of the Directive guarantees the right of suspect and accused persons to remain silent. The right to refuse to testify and not to incriminate himself or herself while 
cooperating with the law enforcement authorities belongs among the generally applicable standards ensuring the right to fair trial as the principle of not self-incrimination.

In the Slovak legal order the right to refuse to testify is contained in Article 50 paragraph 4 of the Constitution of the Slovak Republic, within the meaning of which everyone charged with a criminal offence shall have the right to refuse to give testimony and this right may not be denied to that person under any circumstances.

This right is also regulated in Article 34 paragraph 1 of the Code of Criminal Procedure, according to which the suspect and accused has the right to express himself or herself to all facts related to all charges and related evidence.

Article 8 foresees the ensuring the rights of suspect or accused persons by guaranteeing their rights to be present at the hearing before the court.

The aim is to ensure that the right for defence is respected and that the accused person cannot be held guilty without the opportunity to claim other facts in relation to the reasons for his or her conviction.

This article regulates the proceedings held in absentia as well. The requirements contained in this provision are fully incorporated in the Slovak legal regulation of proceedings in absentia as contained in Article 358 and following, and especially in Article 362 of the Code of Criminal Procedure.

\section{$4 \quad$ Conclusion}

Slovak legislation fully complies to European legislation and useful links where people can find useful information and advice.

1. Council of Europe webpage on criminal justice reform

2. Council of Europe webpage on effective judicial remedies

Factsheets on the case-law of the European Court of Human Rights:

3. Article 6 - the right to a fair trial (civil) PDF $(820 \mathrm{Ko})$

4. Article 6 - the right to a fair trial (criminal) PDF (930 Ko)

5. Police arrest and assistance of a lawyer PDF $(285 \mathrm{Ko})$

6. Handbook on European law relating to access to justice PDF (2,130 Mo)

7. Handbook on Human Rights and Criminal Procedure PDF (2,150 Mo)

Incorporation of European legislation into national legal Acts has resulted into augmenting national legislation and in improving democratic The right to fair trial is an 
essential safeguard of a just society and its significance cannot be overstated. It is an essential guarantee of the rule of law.

\section{Acknowledgment:}

This study is the result of a participation of the Faculty of Management, Comenius University in Bratislava in the EU funded project PRESENT being successfully led and coordinated by the LIF - Law and Internet Foundation, Sofia, Bulgaria in the years 2018-19.

\section{Notes:}

${ }^{1}$ Ú. v. EÚ C 326, 26.10.2012, s. 392.

\section{References:}

Constitution of the Slovak Republic (Act No 460/1992 as amended) [online]. [cit.2019-10-20]. Available at: https://www.nrsr.sk > web > Static > en-US > NRSR > Dokumenty > constitution

Court of Justice EU (2004). Case C-506/04 Graham J. Wilson. [online]. [cit.2019-10-20]. Available at: http://curia.europa. eu/juris/ liste.jsf? language $=$ en $\&$ num $=C-506 / 04$

Directive (EU) 2016/343 of the European Parliament and of the Council of 9 March 2016 on the strengthening of certain aspects of the presumption of innocence and of the right to be present at the trial in criminal proceedings OJ L 65, 11.3.2016, p. 1-11 . [online]. [cit.2019-10-20]. Available at: https://eur-lex.europa.eu/legal-content/EN/TXT/?uri=CELEX\%3A3 2016L0343

Law on the European Investment Order in Criminal Matters . [online]. [cit.2019-10-20]. Available at: [online]. [cit.2019-10-20]. Available at: https://eur-lex.europa.eu/legalcontent/EN/TXT/HTML/?uri=CELEX:32014L0041\&from=EN

Laws No. 236/2017 Coll. as well as by the Code of Criminal Procedure No. 301/2005 Coll. [online]. [cit.2019-10-20]. Available at: https://www.ejn-crimjust.europa.eu/ ejn/EJN_Library_StatusOfImpByCou/EN/368

Treaty on the functioning of the European Union, OJ EU C 83 30.3.2010. [online]. [cit.2019-1020]. Available at: https://eur-lex.europa.eu/legal-content/EN/ALL/?uri=OJ\%3AC\%3A $2010 \% 3 \mathrm{~A} 083 \% 3 \mathrm{ATOC}$

The Charter of the European Union OJ EU C 83 30.3.2010 [online]. [cit.2019-10-20]. Available at: https://eur-lex.europa.eu/legal-content/EN/TXT/?uri=uriserv\%3AOJ.C_.2010. 083.01.0389.01.ENG

The Charter of Fundamental Rights and Basic Freedoms (document enacted in 1991 by the Czechoslovak Federative Republic ) [online]. [cit.2019-10-20]. Available at: http://www.psp.cz/en/docs/laws/listina.html

The European Convention on Human Rights . [online]. [cit.2019-10-20]. Available at: https://www.echr.coe.int/Documents/Convention_ENG.pdf 


\title{
Practical Challenges and Best Practices Regarding the Right to be Present in Austria
}

\section{DANIELA AMANN}

\begin{abstract}
Without being present at trial, an accused person cannot react on charges, dispute evidence, or effectively use procedural rights. Without the right to be present, thus, the right to a fair trial cannot be upheld. The following article summarizes the findings of the PRESENT project in Austria. Overall, the research conducted shows that in Austria the right to be present at trial is not only legally protected, but also guaranteed and enforced. The article pinpoints practical challenges in the application of the right to be present as well as good practices.
\end{abstract}

Keywords: - right to be present - fair trial - right to information • procedural rights $\bullet$ harmonisation $\bullet$ right to be heard

CORRESPONDENCE AdDRESS: Daniela Amann, Vienna Centre for Societal Security, Paulanergasse 4/8, 1040 Wien, Austria, email: daniela.amann@vicesse.eu.

https://doi.org/10.4335/978-961-6842-96-9.67-83

ISBN 978-961-6842-96-9 (pdf)

(C) 2020 Institute for Local Self-Government Maribor

Available online at http://www.lex-localis.press. 
D. Amann: Practical Challenges and Best Practices Regarding the Right to be Present in Austria

\section{$1 \quad$ Introduction}

The right to be present at trial is a fundamental right. Without being present at a trial, an accused person cannot react on charges, dispute evidence, or effectively exercise his or her procedural rights. Without the right to be present, thus, the right to a fair trial cannot be upheld.

While the right to a fair trial is already enshrined in several legal documents on EU level, ${ }^{1}$ "experience has shown that this in itself does not always provide a sufficient degree of trust in the criminal justice systems of other Member States" (Directive 2016/343, recital 5). Due to this reason, the Council of the European Union adopted a Roadmap for strengthening the procedural rights of suspected or accused persons in criminal proceedings. In this scope, Directive 2016/343 (the Directive) was drafted, establishing common minimum rules concerning certain aspects of the presumption of innocence and the right to be present at trial which were to be transposed in April 2018. The PRESENT project (runtime: jan 2018 - dec 2019) took a closer look at the transposition of the Directive in Austria, Bulgaria, Cyprus, Portugal and Romania, in particular to identify challenges and best practices.

The following section presents the research results of the PRESENT project in Austria. As in Austria the right to be present at trial was already a well-established principle before the Directive was introduced, the Austrian research team put a special emphasis on identifying best practice examples and learnings from professionals working in the field. These learnings should serve other Member States as an inspiration how the rights defined in the Directive can be implemented and ensured.

The following article structures as follows. First, a brief overview of the methodology of the research conducted in the scope of PRESENT is provided in Chapter 2. Chapter 3 demonstrates the transposition legislation of the Directive in Austria. The following chapters focus on the application of the existing legislation in practice, while Chapter 4 points out the challenges, and Chapter 5 best practices. Lastly, in Chapter 6 concluding remarks are given, summarizing the research findings.

\section{$2 \quad$ Methodology}

PRESENT is an EU-funded research project with a runtime of two years. The project has the aim to enhance the right to be present at trial for persons suspected or accused of crime, as well as to strengthen certain aspects of the presumption of innocence.

In the first year of the project, two research reports were drafted in each of the participating member states ${ }^{2}$ : a report on the transposition of Directive 2016/343 and a report on statistical data and best practices. In Austria, both reports are based on desk research, in particular legal commentaries and journals, as well as an expert interview 
with an Austrian criminal judge (Interview, 25.07.2018). Moreover, a contrasting juxtaposition of Directive (EU) 2016/343 and the corresponding Austrian law was prepared to pinpoint possible shortcomings in the Austrian legislation. Lastly, an in-depth review of statistical data was conducted.

The second year of the project was dedicated to bringing the research results to practice. In all participating member states, two participatory seminars were conducted with the aim to present the research findings and create a space for discussion and reflection for involved professionals about challenges to the right to be present. Another aim was to identify the most successful and effective measures regarding the implementation and application of Directive 2016/343. In Austria, these seminars took place in Vienna and Graz and participants came from the justice sector, law enforcement agencies, and academia. As a final step, a summary of the discussions was sent to participants with the query for feedback.

\section{A legal analysis: the right to be present at trial}

\subsection{Transposition of Directive 2016/343 in Austria}

In Chapter three, the Directive sets out minimum rules regarding the right to be present at trial. Amongst others, the Directive determines that a trial in absentia may only be held, if the accused 1) has been informed, in due time, of the trial and of the consequences of nonappearance; or if 2) the accused who has been informed of the trial is represented by a mandated lawyer, who was appointed either by the accused or by the State. If the accused cannot be located despite reasonable efforts, decisions may also be held under the condition that the accused has the right to a new trial or another legal remedy which allows a fresh determination of the merits of the case and is informed about this right and the decision of the court.

In Austria the right to be present is a well-established legal principle that already existed before the Directive. The European Convention on Human Rights, including the right to a fair trial under Article 6, for example, has constitutional rank in Austria. Furthermore, partial aspects of the right to a fair trial are defined in the Austrian Code of Criminal Procedure (Strafprozessordnung, StPO), such as the right to a fair hearing, the right to defence and the presumption of innocence. As a consequence, there existed no need to transpose the Directive in Austria. The Austrian legislator did, however, introduce two minor changes to the Austrian Code of Criminal Procedure. These changes are rather formal and are expected to have no impact in practice (Erläuterungen Ministerialentwurf Strafprozessänderungsgesetz 2017). ${ }^{3}$

First, the article determining the information to be included in the summons sent to the procedural parties, including the accused, was changed (§ 221 (1) StPO). A passage was introduced stating that the summons of the accused also must include the information that 
in case of non-appearance, a trial in absentia might be held or that he or she might be brought before a judge by the police. ${ }^{4}$ While before, these regulations were not determined in black-letter law, they were clearly determined in literature and settled case law. Secondly, a new phrase was introduced in the passage regulating the procedure for the placement in a facility for mentally ill offenders (Anstalt für geistig abnorme Rechtsbrecher) ( $\S 429 \mathrm{ff}$ ), according to which the decision to hold a trial in absence of the accused can only be made after the judge made sure that the accused was informed about the date of the main hearing ( $\$ 430$ (5) StPO), amongst others.

\subsection{The rights of the suspect - accused - defendant}

The Austrian criminal law - the Code of Criminal Procedure in particular - differentiates between the roles of the suspect, the accused, and the defendant. Which legal term applies is dependent on the stage of the criminal procedure. They are aimed to ensure that a suspect is not accused of having committed a crime until a concrete suspicion exists. Moreover, the legal term that applies in a specific stage of the procedure has effects on the position and the rights of the person to whom this definition applies. All legal terms are determined in the Austrian Code of Criminal Procedure:

- A suspect (VerdächtigeR) is every person being investigated due to an initial suspicion. An initial suspicion exists, if due to concrete indications it can be assumed that a criminal offence was committed ( $\S 48$ (1) 1 icw 1 (3) StPO). In this phase, either the police or the prosecutor is conducting the investigation.

- An accused (BeschuldigteR) is any suspect, as soon as he or she is concretely suspected of having committed a criminal offence on the basis of certain facts and if in order to solve this concrete suspicion, an investigation procedure was disposed and initiated.

- As soon as the prosecutor introduces a criminal charge (Anklageschrift) or a complaint (Strafantrag) to court, the accused becomes a defendant (AngeklagteR). In general, the nomen iuris remains unchanged until the final decision. There exist also some circumstances under which a trial might be terminated by order of the court (Beschluss) (§ $191 \mathrm{StPO})$.

At all stages - thus, the suspect, the accused and the defendant - have certain rights to information, defence, and procedural participation. For instance, they must be informed as soon as possible that an investigation has been initiated and that there exists a concrete suspicion against them. In general, all provisions of the Austrian Code of Criminal Procedure which refer to the accused are also applicable to suspects and defendants, if the provision does not specify otherwise ( $\$ 48$ (2) StPO).

The accused is a procedural party (BeteiligteR) of the criminal proceeding according to $\$ 220$ StPO. While this provision is only applicable to the criminal proceeding at court and not to the investigation phase, it is accepted that the suspect has a similar position within the investigation phase (§6 (2) StPO) (Wiederin, 2014, RZ 199). 


\subsection{The duty to be present \& trial in absence of the accused}

\begin{tabular}{l|l}
\hline \multicolumn{1}{|c|}{ Directive (EU) 2016/343 } & \multicolumn{1}{c}{ Austrian legislation } \\
\hline $\begin{array}{l}\text { Article 8 - Right to be present at the } \\
\text { trial }\end{array}$ & $\S 6 \mathrm{StPO}-$ Rechtliches Gehör \\
& $\S 427 \mathrm{StPO}-$ Abwesenheitsverfahren \\
& $\S 491 \mathrm{StPO}-$ Mandatsverfahren
\end{tabular}

In Austria, the accused has the duty to be present during the court proceeding ( 6 StPO). The right to participate in the whole criminal procedure, on the other hand, is not a duty. It includes the right of defence, to remain silent, to call for the admission of evidence and to participate in evidence hearings (Wiederin, 2014, RZ 176). A trial can only be held without the presence of an accused person under strict and particular circumstances which are regulated in $\S 427$ (1) StPO. Accordingly, in absence of a suspect, a trial in absentia may only be held if:

a) the suspect is only accused of having committed a minor offence (Vergehen); This means that the offence was committed in negligence (fahrlässig), or was a nonnegligent act punishable by deprivation of liberty for not more than three years; ${ }^{5}$

b) the accused was already heard in the case; This implies that the accused was informed about all accusations and had the possibility to invalidate them. The interrogation might have taken place during the criminal investigation by the police or the prosecutor or via inter-court assistance (Rechtshilfeweg) and must include all information about what offence he or she is accused of, detailed information of the facts of the case as well as their legal implications. Thus, the information must include the entire criminal charge (OGH 15 Os $180 / 15 \mathrm{~g}$ ). It is insignificant whether the accused used his or her right to remain silent during the interrogation (Bauer, 2017). If the accused does not appear at trial, the protocols of the interrogation of the accused may be read out in court according to $\$ 252$ (1) Z1 StPO. In this manner, the principle audi alteram partem is exercised. As a result, any extensions or (essential) modifications of the criminal charge are inadmissible, if the accused has not the possibility to be heard in this manner (Hinterhofer/Oshidari, 2017). The latter includes also a modification of the legal analysis of the case (Stricker, 2015); and

c) the accused was sent a formal summon, which contained all the necessary information; The summon has to contain the date of the proceeding and the information about the consequences of a non-appearance, including the possibility of a trial in absentia ( $\$ 221 \mathrm{StPO})$. Further, the summon also has to include the subject of the trial, the essential facts of the case as well as their legal consequences (Sticker, 2015).

The summons must be sent by a registered personal delivery (persönlich; zu eigenen Handen) ( $\$ 427$ (1) StPO). The latter constitutes a manner of delivery ensuring a particular level of security for the recipient. The idea of the registered personal delivery is that the recipient receives a "direct notice" from the delivery. The delivery cannot be accepted by another person than the recipient (Meter, Pirklbauer, 2014). After the delivery has been 
D. Amann: Practical Challenges and Best Practices Regarding the Right to be Present in Austria

completed, the recipient must sign a receiving confirmation (Rückschein). ${ }^{6}$ The receiving confirmation is noted in an internal system, to which the responsible criminal judge and his or her office has direct access (Interview, 25.07.2018). The signed receiving confirmation is sufficient proof that the accused has received the summon (Interview, 25.07.2018).

According to case law, a delivery by deposit is sufficient for that the accused is considered as duly notified (OGH 11 Os 19/05m; RIS-Justiz RS0120038). In this case, the delivery is effective on the day after the deposit (§ 17 (3) Service of Documents Act, Zustellgesetz, ZustG). If the accused was absent from the place of delivery, the delivery is only effective on the day following his or her return (§ 17 (3) ZustG). If the accused does not collect the summons, it is still assumed that the summons was delivered, if the accused was present at his or her home (ortsanwesend) during the two-weeks period in which it was possible for the accused to collect the summons. The procedure to verify the presence of the accused is conducted by the police following an order by the court (Interview, 25.07.2018). Only if the accused or his or her representative was unable to obtain knowledge of the delivery in time, due to absence from the place of delivery, the delivery is not accepted as effective.

If these three conditions prevail and the judge does not deem the presence of the accused necessary for the comprehensive evaluation of the case, a decision on guilt or innocence may be made. In this case, the verdict has to be issued in written form to the accused.

If the conditions do not prevail, the proceeding must be adjourned and - if necessary the judge can order that the accused is to be brought before a judge by the police ( $\$ 427$ (2) StPO). If the residence of the accused is unknown or the accused is fugitive, the investigation must be continued as far as it is necessary to preserve traces and perpetuate evidence. Under these conditions, investigations in which the accused generally has the right to participation may be conducted also without his or her presence. The judge may order to investigate the residence of the accused, to de-registrate the accused of the residence where he or she could not be found or issue a warrant (Interview, 25.07.2018). Subsequently, the prosecutor's office has to interrupt the proceeding and continue after the exploration of the accused ( $\S \$ 427$ (2) icw 197 (1)). This decision is, however, not a formal order of the Court (Beschluss). Thus, there exists no appeal mechanism against this order.

According to case law and prevailing opinion in the literature, an accused adult can waive his or her right to be present at trial through a personal and unambiguous declaration (RISJustiz RS0115797; ECHR, Jones v. The United Kingdom, 9 September 2003, no. 30900/02). Presumed that the accused was informed about the consequences beforehand, a premature departure of the criminal trial or the deliberate bringing about of the inability for trial might be equated with such a declaration (Hinterhofer/Oshidari, 2017). 
Legal remedies: The right to a new trial

Directive (EU) 2016/343

Article 9 - Right to a new trial
Austrian legislation

$\S 427$ (3) StPO - Abwesenheitsverfahren

§ 281 (1) Z 3 StPO - Nichtigkeitsbeschwerde

$\S 489$ (1) StPO - Berufung wegen Nichtigkeit

The accused or his or her counsel may lodge an appeal (Einspruch) against a verdict which was made in absentia of the accused within fourteen days after the receipt of the verdict ( $\$ 427$ (3) StPO). ${ }^{7}$ The accused must be informed about this right. This legal remedy is not fighting the decision, but that the sentenced in absentia did not have the possibility to be present at trial, thus, the procedure that lead to the verdict. This means that the sentenced appeals the sentence of the fact that he or she was not duly informed and thus unable to exercise his or her procedural rights. For the appeal to be successful, the accused must prove that an irrefutable obstacle (unabweisbares Hindernis) prevented him or her from being present at trial. This includes, for example, delivery shortcomings or incomprehensible instructions of the court.

If the appeal is successful, the verdict will be reversed, and the case will be sent back to the court of first instance (Hinterhofer/Oshidari, 2017). If the appeal is rejected by the Supreme Court of Justice (Oberster Gerichtshof, $O G H$ ), no legal remedies are admissible. If the appeal is rejected by a District Court (Bezirksgericht) as cour of first instance, a further appeal may be logged to the competent Regional Court (Landesgericht) (§ 478 (2) StPO).

Further, a breach of the right to be heard constitutes a breach of the right to a fair trial and might, thus, lead to the nullity of the verdict. An appeal for nullity is an extraordinary legal remedy that can only be introduced in exceptional cases of serious procedural errors. The special characteristic of this legal remedy is that it is not bound to deadlines and that it gives the accused the right to request a new hearing even after the judgment has become final. Thus, along with or instead of the appeal (Einspruch) the accused may contest the verdict either by using an appeal for nullity (Nichtigkeitsbeschwerde - $\$ 281$ (1) 3 icw $427 \mathrm{StPO}$ ) or an appeal because of nullity (Berufung wegen Nichtigkeit - $\S 489$ (1) icw 427 (3) StPO), depending on the court which issued the verdict.

\section{The Austrian "Mandatsverfahren"}

Since 2015 there exists a special procedure which allows a penal order (schriftliche Strafverfügung) to be issued under specific circumstances without holding an oral court proceeding (Mandatsverfahren). This procedure is intended to conserve resources and accelerate the process, while at the same time upholding the rights of the accused. One of the preconditions for the admissibility of this procedure is, that the result of the investigation, in connection with the responsibility of the accused, is sufficient for the 
court to assess all the circumstances relevant for the decision. Further, the sentence can only impose a fine or a conditional sentence of not more than one year's imprisonment. According to the legislative materials, the Mandatsverfahren should be carried out without impairing the right to a fair trial according to Article 6 of the ECHR (Bundesministerium für Justiz, 2017). Due to this reason, a further precondition for admissibility of this procedure is that the accused must explicitly forgo the possibility of a criminal proceeding to be held ( $\$ 491$ (1) 1 StPO) while he must have been informed in advance of all consequences. The accused must also be informed of his right to appeal the decision. The appeal may be lodged within 4 weeks of the receipt of the criminal ruling and does not need to contain any reasoning. The public prosecutor and the victim can also lodge an appeal within 4 weeks ( $\$ 491$ (6) and (8) StPO). In case of an appeal, the main proceedings must be initiated.

\section{The right to be present in practice}

\subsection{Challenges to the right to be present}

From a legal perspective, the right of the accused to be present at trial is guaranteed through several regulations and mechanisms. Nevertheless, there still exist challenges from a practical point of view. These challenges include the lack of statistical data and systematic empirical studies on trials held in absentia, administrative difficulties to ensure that every accused person is duly notified, and questions on the correct interpretation of the law. The following section pinpoints the challenges to the right to be present in Austria that could be identified in the scope of the PRESENT project. These challenges were extracted from discussions between representatives from the judicial sector, law enforcement agencies and academia.

Austria: Challenges to the right to be present at trial
a) No data available on trials in absentia
b) The right to a translator and interpreter
c) Personal delivery of the summons: is the deposit sufficient?
d) Audi alteram partem: reading out documents in absence of the
e) Registered personal delivery in other countries

\section{a) No data available on trials in absentia}

Over the course of criminal proceedings, the following bureaucratic data sources are collected by Austrian authorities: crime reports, ${ }^{8}$ number of criminal trials, ${ }^{9}$ verdicts ${ }^{10}$ and others. None of the latter, however, collects data concerning trials in absentia. Only two sets of data within these ministerial statistics record indirect references to trials in absentia: first, the number of trials which had to be interrupted due to the absence of an accused person (16.580 in 2017); ${ }^{11}$ and second, the number of appeals against trials in 
absentia. The documentation of data relating to trials in absentia, hence, is underdeveloped and does not provide a systematic record on an on-going basis.

Statistical data is necessary in order to systematically assess the quality of trials conducted in absence of the accused person over a longer period of time. Without the relevant data and information, it is impossible to conduct a profound comparative analysis on a European or international level nor to identify in depth which local legislation and practices appear promising. What is remarkable, is the fact that in addition to the lack of official data sources recording trials in absentia, there are virtually no systematic empirical studies on the subject. ${ }^{12}$ The available literature is limited to questions of procedural law and a variety of human rights implications in respect to the extraordinary circumstances a trial in absentia poses.

\section{b) The right to a translator and interpreter}

Being able to understand and communicate with law enforcement agencies and court officials is a prerequisite for the effective exercise of any other right an accused or suspected person has. The necessity for having a good translator and interpreter during the very first interrogation by the police, receives even more importance in the light of the legal framework of trials in absentia: In absence of the accused, the testimony of the accused person may be read out in court (see below for a critique on this practice). Regarding this fact, two practical problems were discussed with professionals in Austria.

First, the decision if a translator and interpreter is required, thus, if the suspected or accused person speaks sufficient German, varies depending on the official in charge of taking this decision. In practice, police officials consider the appointment of a translator necessary in fewer circumstances than judges (Interview, 25.07.2018). In the case of a trial in absentia, however, a judge only reads out the police documentation. In these cases, no judge can verify whether the accused person spoke sufficient German to be interviewed without a translator, having to trust the evaluation made by the police.

Secondly, while in court, only registered court translators can be appointed, there does not exist any specific requirements for the translators appointed by the police. According to our expert interview, it is often difficult to assess how good a translator is during the first interview, if he or she is not listed in the official court translator register. Moreover, in the case of a trial in absentia, it is ultimately impossible to assess mistakes that were made during the interview of the accused in the preliminary investigation phase (Interview, 25.07.2018).

\section{c) Personal delivery of the summons: is the deposit sufficient?}

One of the admissibility criteria for a trial in absentia is, that the summons was sent personally (persönlich zugestellt, § 427 (1) StPO). According to the Austrian Code of Criminal Procedure, every letter that is decisive for time limit for the submission of an appeal, must be sent by registered personal delivery (zu eigenen Handen) (§ 83 (3) StPO). 
D. Amann: Practical Challenges and Best Practices Regarding the Right to be Present in Austria

As previously described, the latter constitutes a form of delivery with a particular security for the recipient, in which the recipient receives "direct notice" from the delivery. The respective provision of the Austrian Code of Criminal Procedure refers to the Service of Documents Act, which determines that the summons may not be accepted by another person than the recipient $(\S 21 \mathrm{ZustG}) .{ }^{13}$ The delivery is generally performed by the Austrian Post as delivery service ( $\$ 12$ Postal-market law, Postmarktgesetz, PMG). After having received the delivery, the recipient must sign a receiving confirmation (Rückschein) (§ 22 ZustG).

According to settled case law, a delivery by deposit is sufficient (OGH 11 Os 19/05m; RIS-Justiz RS0120038). However, it is questioned whether the deposit of the summons is fulfilling the required standards. In fact, the wording used in $\S 427$ (1) StPO ("persönlich") can be found neither in the Service of Documents Act, nor in the Code of Civil Procedure (Zivilprozessordnung, ZPO), but only in $\S 427$ (1) StPO which determines trials in absentia. Following this argumentation, it is argued that the delivery through deposit can only be sufficient if the recipient had the possibility to collect the summons. According to the currently applied law, however, also in the case of the disappearance of the notification - and out of this reason the impossibility to collect the summons - the delivery is seen as valid. (See further: Sticker, 2015).

\section{d) Audi alteram partem: reading out documents in absence of the accused}

All court proceedings in Austria must be held orally and publicly, while exceptions may be determined by law. ${ }^{14}$ Accordingly, the verdict in a criminal proceeding can only be based on evidence that was recorded in the criminal trial. This is the reason why the practice of reading out earlier statements or other minutes - instead of gathering primary evidence in court - is only admissible under narrow conditions determined in the Code of Criminal Procedure. ${ }^{15}$ Under other circumstances reading out documents in the criminal trial is only admissible if all parties to the proceeding - including the accused agree to do so ( $\$ 252$ (2a) StPO). This agreement may also be conclusive, while the failure of objection to the reading cannot be understood as an approval. Rather, more concrete evidence must persist that clearly indicates the accused approval (Rointer, 2015).

Following these provisions, it is permissible to read out - and consider - only certain documents if the accused is absent from the trial. Which documents can be read out, however, is not clearly defined by law (Interview, 25.07.2018). ${ }^{16}$ Nevertheless, it is common practice that in the case of a trial in absentia witness testimonies are often read out by mutual agreement (einvernehmlich). Scholars criticise that from the absence of the accused, no agreement to this procedure can be deduced (Hinterhofer/Oshidari, 2017, Rz 10.106).

\section{e) Registered personal delivery in other countries}

How summons or verdicts must be sent to people resident outside of Austria is determined in numerous bilateral and multilateral treaties (Meter, Pirklbauer, 2014; 111 ZustG). In 
general, a delivery outside of Austria must be suitable to have legal effects in Austria. If no international treaty exists, the law of the recipient state is to be applied in order to decide whether the delivery was legitimate (Meter, Pirklbauer, 2014; , 11 (1) ZustG). The Austrian Supreme Court argues that a recipient who lives in another country cannot rely on Austrian laws on the delivery of documents, but only on those applicable to the country he or she resides in (RIS-Justiz: RS0119937). Authors have questioned this practice, arguing that it differentiates the rights of accused people in Austria and other countries resulting in "two classes of delivery" (translation by the author; Meter, Pirklbauer, 2014).

In practice, when sending verdicts from Austrian criminal courts to an accused person in other countries in the EU, they are either sent by international confirmation delivery (internationaler Rückschein) or via inter-court assistance (Rechtshilfe) (Meter, Pirklbauer, 2014).

\subsection{Good practices from Austria}

One of the central aims of the PRESENT project was to identify workable solutions on how the right of the accused to be present at trial can be applied in practice. Due to the distinct legal frameworks and existing administrative systems in place in EU member states, every country inevitably produces divergent answers for transposing and implementing EU directives on national level. Nevertheless, good practices can serve as inspiration to identify transposition legislation.

Overall the research conducted in Austria shows that the right to be present at trial is not only enshrined in several legal documents, but also guaranteed and enforced. The following section will pinpoint good practices.

\section{Austria: Good practices for ensuring the accused persons' right to be present}

\section{at trial}
a) A well-developed and functioning residency register \& postal service
b) Summoning accused persons: "registered personal delivery"
c) Voluntary notification of absence
d) The judges' discretion as an important prerequisite for a fair trial
e) Cancelation and resumption of the criminal proceedings

\section{a) A well-developed and functioning residency register \& postal service}

The well-developed and functioning national administrative system - including the residency register and the postal system - is one of the most important prerequisites for ensuring the summoning of the accused in Austria. In general, the Austrian Post performs the delivery of judicial documents and ensures that the recipient signs a receiving confirmation. Only if the accused person is not listed in the residency register or not reachable at his or her residency, the responsible judge will request that the police detects 
D. Amann: Practical Challenges and Best Practices Regarding the Right to be Present in Austria

the accused person's residence or whereabouts in order to inform him or her about the accusation as well as to deliver the summons. The Austrian example shows therefore, that the more effective the residency registration system and the postal system work, the more tasks can be taken over by the postal service and, hence, have not to be performed by the judiciary or police. Therefore, Austrian experts highlighted the importance of a wellfunctioning administration system with effective mail delivery services on the national level.

The rules regarding the registration in the nationwide residence register ${ }^{17}$ in Austria are quite strict: Every person living in Austria must be registered and there exists a limited time frame in which a person must report a change of residency. The latter can be done in three ways: in person, via mail, or delivered by a person of trust. It is necessary to fill out a residence registration form (Meldezettel-Formular), which can either be downloaded online or picked up at the registration authority. Online, however, the form is only available in German. In several other EU member states, no nationwide residence register exists, causing ambiguity regarding mail deliveries, for example, in cases with wrong or outdated addresses making deliveries less successful.

\section{b) Summoning accused persons: "registered personal delivery"}

According to the Austrian Code of Criminal Procedure, every court letter that causes a time limit in which an appeal must be submitted, must be sent by "registered personal delivery" (zu eigenen Handen, see $\S 83$ (3) StPO). If a letter is sent via this delivery method, the letter can be only received personally by the recipient and by no other person. After having received the delivery, the recipient must sign a receiving confirmation (Rückschein), which is noted in an internal system, to which the responsible criminal judge and his or her office has direct access. The signed receiving confirmation is sufficient proof that the accused has received the summons. The idea of the registered personal delivery is, thus, that the recipient receives "direct notice" from the delivery and that there exists a certain proof that - and when - the recipient received a letter.

The delivery of the summons is generally performed by the Austrian Post as delivery service. As this mailing method ensures that the accused person has been personally informed about the charges against him or her, participants identified it as a promising practice.

Further, in practice judges may also call the accused to ask about his or her location and why he or she did not come to trial. If the accused person forgot about the trial, the judge may allow the accused some time to come to court (Interview, 25.07.2018).

\section{c) Voluntary notification of absence}

The Austrian post offers the service of a notification of absence (Abwesenheitsmitteilung) as a form of voluntarily notifying authorities when travelling. With this notification, every resident of Austria has the option of having incoming formal letters (RSa or RSb-Briefe) 
returned to authorities and public offices in their absence. This notification can be made in a post office, or online on the webpage of the Austrian Post. While the settled case law does not require residents to make such a notification of absence, this option makes procedures less complicated and cheaper.

\section{d) The judges' discretion as an important prerequisite for a fair trial}

If all legal requirements to hold a trial in absentia are met in Austria, it is ultimately the judge who decides if a judgment will be taken in the absence of the accused person. As an unlawful judgment in absentia may lead to the nullity of the verdict, Austrian judges tend to uphold the legal requirements particularly well. The discretion of the judge is therefore an essential prerequisite for the protection of the right to be present at trial and can be regarded as good practice, if exercised with due diligence. Against this background, the awareness of judges for the (procedural) rights of the accused, is to be considered a crucial factor for the protection of the right to be present.

\section{e) Cancelation and resumption of the criminal proceedings}

If the conditions to hold a trial in absentia do not prevail, the proceeding must be adjourned and - if necessary - a demonstration of the accused must be ordered. Not seldomly, the residence of the accused is unknown, and the investigation must be continued to investigate the accused persons' whereabouts. These proceedings can take long, and the accused person may never be found. Due to this cause, the Austrian legislation provides the possibility to stop the proceeding (Abbruch) and to resume them as soon as the accused was located.

\section{$5 \quad$ Conclusion}

The PRESENT project is an EU-funded research project with a runtime of two years that was conducted in five EU member states. The main aim of the project is to enhance the right to be present at trial for persons suspected or accused of crime, as well as to strengthen certain aspects of the presumption of innocence. Overall, the research conducted in the scope of the PRESENT project shows that in Austria the right to be present at trial is not only enshrined in several legal documents, but also guaranteed and enforced.

Form a legal perspective, there existed no need for implementation measures in Austria as all the rights enshrined in Directive (EU) 2016/343 already existed before the Directive. Only two minor changes were introduced to the Austrian Code of Criminal Procedure which were rather formal and are expected to have no impact in practice. In Austria, a trial in absentia may only be held under the strict regulations laid down in $\S$ 427 StPO. These requirements include that the suspect is only accused of having committed a minor offence (Vergehen), that the accused was already heard in the case 
D. Amann: Practical Challenges and Best Practices Regarding the Right to be Present in Austria

and that he or she was sent a formal summons, which contained all necessary information about the case and the possible consequences of not appearing at trial.

The practical application of the Directive was examined during two participatory seminars that were conducted in the second half of the research project. In the course of these seminars, the research findings were discussed with representatives from the justice sector, law enforcement agencies and academia with the aim to identify challenges to the right to be present as well as good working practices.

While from a legal perspective, the right to be present at trail is guaranteed through several regulations and mechanism, there still exist challenges. These challenges include the lack of statistical data and systematic empirical studies on trials held in absentia, administrative difficulties to ensure that every accused person is notified, and questions on the correct interpretation of the law.

Further, several good practices could be identified in Austria. These good practices must be viewed in the light that every member state works in distinct legal frameworks and existing administrative systems and, thus, inevitably produces divergent answers for transposing and implementing EU directives on national level. In Austria practitioners pointed out the well-developed and functioning residency register and postal service as best practice. They argued that the more effective the residency registration system and the postal system are, the more tasks can be taken over by the postal service and, hence, have not to be performed by the judiciary or police. Also, the summoning of the accused person via "registered personal delivery", a manner of delivery that can only be accepted by the recipient was identified as good Austrian practice.

\section{Notes:}

${ }^{1}$ The Charter of Fundamental Rights of the European Union, the European Convention for the Protection of Human Rights and Fundamental Freedoms

${ }^{2}$ Austria, Bulgaria, Cyprus, Portugal and Romania.

${ }^{3}$ The law introducing these changes is the Bundesgesetz, mit dem die Strafprozessordnung 1975 geändert wird (Strafprozessrechtsänderungsgesetz 2017). All changes were implemented in the Austrian Code of Criminal Procedure (StPO).

4 "Die Ladung des Angeklagten hat die Androhung zu enthalten, dass im Falle seines Nichterscheinens je nach den Umständen entweder die Hauptverhandlung und Urteilsfällung in seiner Abwesenheit vorgenommen oder seine Vorführung angeordnet oder, falls dies nicht zeitgerecht möglich ist, die Hauptverhandlung auf seine Kosten vertagt und er zur Verhandlung vorgeführt wird."

${ }^{5}$ This is also applicable in the case of financial crimes according to the Law on financial crimes (Finanzstrafgesetz).

${ }^{6}$ For a more detailed assessment of the requirements of the registered personal delivery please see chapter V, subchapter 1 . The deposit of the summons.

${ }^{7}$ A second norm - $\S 478 \mathrm{StPO}$ - determines provisions of the trial in absentia of the accused in front of a District Court. There only exist minimal differences between these two procedures. (for further 
information see Stricker, Das Abwesenheitsverfahren in der Strafprozessornung, ÖJZ 2015/8/2, 61 ff)

${ }^{8}$ Police Crime Statistics (Polizeiliche Kriminalstatistik, $P K S$ ): published by the Ministry of Interior (quarter) annually; Annual Safety Report on the Policy (polizeilicher Sicherheitsbericht): published jointly by the Ministry of Interior and the Ministry of Justice;

${ }^{9}$ Statistics of the prosecutor's office documents (staatsanwaltschaftliche Statistik): not publicly available,

${ }^{10}$ Court Crime Statistics (Gerichtliche Kriminalstatistik): published annually by the Statistics Austria; Annual safety report (Sicherheitsbericht): published by the Ministry of Justice and Ministry of Interior; Justice Process Automation (Verfahrensautomation Justiz): not publicly available,

${ }^{11}$ Bundesministerium für Verfassung, Reformen, Deregulierung und Justiz, Sicherheitsbericht 2017: Bericht über die Tätigkeit der Strafjustiz, p.12.

12 This is not only the case for Austria, but seems to hold true for most Member States.

${ }^{13}$ If the accused has a mandated counsel, the summons is to be sent to him/her according to $\S 83$

(4) StPO. The verdict of a trial in absentia must be, however, always be sent to the accused.

${ }^{14}$ Article 90 Austrian Constitution, Bundesverfassung (B-VG)

${ }^{15}$ According to $\S 252$ (1) StPO, reading out earlier statements is only admissible: If the person is prevented from personal appearance at court (death, illness, significant other reasons); if the person being interviewed in main proceedings deviates essentially from previous statements, if a witness unjustifiably refuses to testify, or if co-defendants deny the statement; or if a witness is entitled to refuse to testify and the earlier statement has been filed as part of adversarial hearing.

${ }^{16}$ Also, Rointer (2015) critically questions the settled case law according to which a conclusive agreement of the accused is enough for a legitimate reading of all documents.

${ }^{17}$ Zentrales Melderegister, www.bmi.gv.at/413/.

\section{References:}

Bauer, J. (2017) Kommentar zu StPO § 427, Fuchs/Ratz (eds), Wiener Kommentar zur Strafprozessordnung, Stand 22.2.2017, rdb.at.

Bundesministerium für Justiz (2017) Mandatsverfahren - Bericht gemäß Punkt 3. Der Entschließung des Nationalrats vom 10. Juli 2014 betreffend die Sicherstellung einer opfergerechten Abwicklung des Mandatsverfahrens Nr. 38/E XXV. GP, available at: https://www.parlament.gv.at/PAKT/VHG/XXV/III/III_00414/imfname_644422.pdf (January 27, 2020).

Erläuterungen Ministerialentwurf Strafprozessänderungsgesetz 2017, 325/ME XXV. GP, https://www.parlament.gv.at/PAKT/VHG/XXV/ME/ME_00325/fname_646628.pdf (January 27, 2020).

Hinterhofer, H. \& Oshidari B. (2017) System des österreichischen Strafverfahrens (Stand 1.3.2017, rdb.at).

Meter M. \& Pirklbauer C. (2014) Die Zustellung österreichischer Abwesenheitsurteile nach Deutschland, Österreichische Richterzeitung (3), pp. 50f.

Rointer (2015) Die „einvernehmliche“ Verlesung von Protokollen - zur Anwendung des $§ 252$ Abs $1 \mathrm{Z} 4 \mathrm{StPO}$ in der Praxis und den damit verbundenen Problemen, Österreichisches Anwaltsblatt (9), pp. 463 ff.

Stricker (2015) Das Abwesenheitsverfahren in der Strafprozessordnung, Österreichische JuristenZeitung (2), pp. $61 \mathrm{ff}$. 
D. Amann: Practical Challenges and Best Practices Regarding the Right to be Present in Austria

Wiederin (2014) Kommentar zu StPO § 6, Fuchs/Ratz (eds), Wiener Kommentar zur Strafprozessordnung, Stand 1.9.2014, rdb.at.

\section{Decisions:}

ECHR, Jones v. The United Kingdom, 9 September 2003, no. 30900/02.

OGH 11 Os 19/05m regarding $\$ 427$ (1) StPO and $\$ 17$ (1) ZustG, RIS-Justiz RS0120038, https://ris.bka.gv.at/Dokument.wxe?ResultFunctionToken=db4937b4-820c-47e1-b7a4f33c75e $5 \mathrm{~d} 7 \mathrm{e} 0 \&$ Position $=1 \&$ Abfrage $=$ Justiz $\&$ Gericht $=\&$ Rechtssatznummer $=$ RS $0120038 \&$ Re chtssatz $=\&$ Fundstelle $=\&$ AenderungenSeit $=$ Undefined $\&$ SucheNachRechtssatz $=$ True $\&$ SucheN achText $=$ False $\&$ GZ $=\&$ VonDatum $=\&$ BisDatum $=19.07 .2018 \&$ Norm $=\& I m R i s S e i t V o n D a t u m=$ $\&$ ImRisSeitBisDatum $=\& I m R i s S e i t=$ Undefined $\&$ ResultPageSize $=100 \&$ Suchworte $=\&$ Dokum entnummer=JJR_20050607_OGH0002_01100S00019_05M0000_001（last accessed 27.1.2020).

OGH 15 Os $180 / 15 \mathrm{~g}$ regarding $\$ 427$ (1) StPO, RIS-Justiz RS0130532, https://ris.bka.gv.at/Dokument.wxe?ResultFunctionToken=19dd06cf-e456-4078-a4a8-

cfab715ef8e4\&Position $=1 \&$ Abfrage $=$ Justiz $\&$ Gericht $=\&$ Rechtssatznummer $=$ RS0130532 $\&$ Re chtssatz $=\&$ Fundstelle $=\&$ AenderungenSeit $=$ Undefined $\&$ SucheNachRechtssatz $=$ True $\&$ SucheN achText $=$ False $\& \mathrm{GZ}=\&$ VonDatum $=\&$ BisDatum $=19.07 .2018 \&$ Norm $=\&$ ImRisSeit VonDatum $=$ $\&$ ImRisSeitBisDatum $=\&$ ImRisSeit $=$ Undefined $\&$ ResultPageSize $=100 \&$ Suchworte $=\&$ Dokum entnummer=JJR_20160113_OGH0002_01500S00180_15G0000_001 (last accessed 27.1.2020).

RIS-Justiz RS0115797 regarding $\$ 427 \quad$ StPO, $\$ 281 \quad$ (1) Z3 $\quad$ StPO, https://ris.bka.gv.at/Dokument.wxe?ResultFunctionToken=6f6893b2-56c4-46ea-b1da4585f34aa9a9 \&Position $=1 \&$ Abfrage $=$ Justiz $\&$ Gericht $=\&$ Rechtssatznummer $=$ RS0115797 \&Re chtssatz $=\&$ Fundstelle $=\&$ AenderungenSeit $=$ Undefined $\&$ SucheNachRechtssatz $=$ True $\&$ SucheN achText $=$ False $\& \mathrm{GZ}=\&$ VonDatum $=\&$ BisDatum $=19.07 .2018 \&$ Norm $=\& I m R i s S e i t V o n D a t u m=$ $\&$ ImRisSeitBisDatum $=\&$ ImRisSeit $=$ Undefined $\&$ ResultPageSize $=100 \&$ Suchworte $=\&$ Dokum entnummer=JJR_20010831_OGH0002_01400S00079_9900000_001（last accessed 27.1.2020).

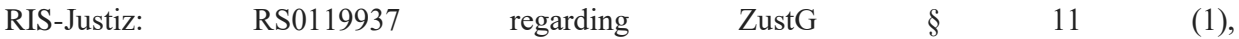
https://ris.bka.gv.at/Dokument.wxe?ResultFunctionToken=625ae179-0a69-4f9d-87ad-

2890e1db54ac\&Position=1\&Abfrage=Justiz\&Gericht=\&Rechtssatznummer $=$ RS01 19937\&Re chtssatz $=\&$ Fundstelle $=\&$ AenderungenSeit $=$ Undefined $\&$ SucheNachRechtssatz $=$ True $\&$ SucheN achText $=$ False $\&$ GZ $=\&$ VonDatum $=\&$ BisDatum $=19.07 .2018 \&$ Norm $=\& I m R i s S e i t V o n D a t u m=$ $\&$ ImRisSeitBisDatum $=\&$ ImRisSeit $=$ Undefined $\&$ ResultPageSize $=100 \&$ Suchworte $=\&$ Dokum entnummer=JJR_20050426_OGH0002_00400B00060_05K0000_002（last accessed 27.1.2020).

Statistical Data:

Bundesministerium für Inneres - Bundeskriminalamt, Polizeiliche Kriminalstatistik (Police Crime Statistics), https://bundeskriminalamt.at/501/start.aspx (last accessed 27.1.2020).

Bundesministerium für Inneres - Bundeskriminalamt, polizeilicher Sicherheitsbericht (Annual Safety Report of the Police), https://bundeskriminalamt.at/501/start.aspx (January 27, 2020).

Bundesministerium für Verfassung, Reformen, Deregulierung und Justiz, Sicherheitsbericht (National Safety Report): https://www.justiz.gv.at/web2013/home/justiz/daten-undfakten/berichte/sicherheitsberichte 2c94848525f84a630132fdbd2cc85c91.de.html (January 27, 2020). 
Statistik Austria, Gerichtliche Kriminalstatistik (Court Crime Statistics), http://www.statistik.at/web_de/statistiken/menschen_und_gesellschaft/soziales/kriminalitaet/i ndex.html (January 27, 2020).

\section{Laws:}

Austrian Code of Civil Procedure, Gesetz vom 1. August 1895, über das gerichtliche Verfahren in bürgerlichen Rechtsstreitigkeiten (Zivilprozessordnung - ZPO), StF: RGB1. Nr. 113/1895.

Austrian Code of Criminal Procedure, Strafprozessordnung 1975 (StPO), StF: BGB1. Nr. 631/1975 (WV)

Austrian Postal-market law, Bundesgesetz über die Regulierung des Postmarktes (PostmarktgesetzPMG), StF: BGB1. I Nr. 123/2009 (NR: GP XXIV RV 319 AB 459 S. 45. BR: AB 8203 S. 778.)

Austrian Service of Documents Act, Bundesgesetz über die Zustellung behördlicher Dokumente (Zustellgesetz - ZustG), StF: BGBl. Nr. 200/1982 (NR: GP XV RV 162 AB 1050 S. 110. BR: S. 421.)

Directive (EU) 2016/343 of the European Parliament and of the Council of March 2016 on the strengthening of certain aspects of the presumption of innocence and of the right to be present at the trial in criminal proceedings, OJ L 65, 11.3.2016, 1-11.

\section{Others:}

Interview, Criminal Judge District Court, 25.07.2018. 